Annals of Warsaw University of Life Sciences - SGGW

Land Reclamation No 50 (3), 2018: 273-286

(Ann. Warsaw Univ. of Life Sci. - SGGW, Land Reclam. 50 (3), 2018)

\title{
Environmental effects of temperature rise and long periods without precipitation on soil processes - case study for southern Slovakia
}

\author{
LUBOŠ JURÍK ${ }^{1}$, PETER HALAJ ${ }^{1}$, TATIANA KALETOVÁ ${ }^{1}$, JÓZEF MOSIEJ ${ }^{2}$, \\ JOZEFÍNA POKRÝVKOVÁ ${ }^{1}$, MIROSLAVA SEDMÁKOVÁ ${ }^{1}$ \\ ${ }^{1}$ Faculty of Horticulture and Landscape Engineering, Slovak University of Agriculture in Nitra, Slo- \\ vakia \\ ${ }^{2}$ Faculty of Civil and Environmental Engineering, Warsaw University of Life Sciences -SGGW, Poland
}

\begin{abstract}
Environmental effects of temperature rise and long periods without precipitation on soil processes - case study for southern Slovakia. The general purpose of the article is to evaluate the environmental effects of temperature rise and long periods without precipitation on soil processes in southern Slovakia. Observed climate change (increase in average temperature) can cause changes in the fertility of the soil, especially in the direction of faster mineralization of organic matter. As an example, very accurate measurements of air temperature, rainfall and water content in the soil profile to a depth of $1 \mathrm{~m}$ are used. The more specific objective of the study was to evaluate the formation of soil water retention resources under high temperature conditions and over 30 days without rainfall. Based on the measured values, they were created graphs for extended period of time without precipitation. The graph shows the average daily soil moisture in each layer, which is measured at the hydrological network of stations in operation by Centre of Excellence for Integrated River Basin Management at SUA in Nitra. The final evaluation for the stations Žirany and Dolné Naštice, soil water content is showing the vulnerability of crops due to changes in water content, especially in layers from 0.3 to $0.5 \mathrm{~m}$.
\end{abstract}

Key words: heat balance, water balance, hydrothermal factor, soil drought

\section{INTRODUCTION}

Observed climate changes also modify environmental effects of agriculture-like degradation of organic matter in soils accompanying severe and long-lasting droughts. It results from thermodynamics that in warmer climate there is more room for water vapor in the atmosphere. As expected, the intensity of precipitation has been increasing in the warmer worlds. Longer dry periods are interspersed by intense rain fall may lead to floods (Kundzewicz and Kozyra 2017).

Drought is a natural phenomenon, occurring several times in human history and often is neglecting the impact and the importance. Numerous droughts have hit European agriculture over the ages, but their overall extent has been known mainly from scattered historical documents. Worst drought and famine ever seen in Europe, the Great Famine of 1315-1317, was actually a series of crises. The tragedy, that killed an estimated 7.5 million people, was caused by strange weather and unrelenting rains (Benedictov 2004). The historical measurements of climate data convince us of 
the severity of the drought on the territory of Slovakia or the former Czechoslovakia.

Drought raises problems especially for agriculture, where water shortage due to heat increases evapotranspiration and soil water consumption, and the situation is worsens. The forests also suffer greatly from during the dry season, like agriculture. And that's a serious problem not only for the trees or vegetation as well as for animals in the forests (Lindner 2000, Keenan 2015, Sohn et al. 2016).

And followed drought brings the problems for the cities; the water supply from the lack of water infiltration is threatened.

Drought is the phenomenon whose signalling it is necessary the longer period. During the drought almost never know that starting drought and also we cannot accurately predict when ends (Laaha et al. 2015, Naumann et al. 2015, Sútor and Rehák 1999). In contrast to the flooding, this began after major or longer rain event, unexpectedly and very quickly. The flood takes a short period, maximum to a few days; the drought takes a long period.

After the floods, almost immediately being reported damages caused by floods. The damages caused by the drought are hardly documented and their actual value can be quantified sometimes after several months, for example after the crop harvest. Therefore, these damages are not published sufficiently. Drought damage generally affects a much larger area than flood (Naumann et al. 2015). The drought is affecting the territory of the states or part of the continent; floods have been associated with river basins or small areas.

Despite the damage, caused by drought, is not given to its observation more relevant attention. Observations of drought are not comparable with the observation of the floods.

The basis of drought observations is countrywide and continuously monitoring of soil water content. Monitoring of groundwater level is not sufficient for assessing drought. Slovakia has the solvable deficiencies in drought monitoring. More detail aim of this paper is to evaluate the state of emergency for the territory over the drought on basis of monitoring results at two locations in Slovakia.

\section{OPTIMIZATION CRITERIA OF HUMIDITY CONDITIONS IN THE RECLAIMED AREAS - BASIC CRITERIA}

One of the most important and most comfortable to use in practice and theory of forecasting the effects of land reclamation called in the literature "maturation drainage soils" is a hydrothermal factor is "radiative index of dryness". Using this indicator can be on a scale larger areas to predict the effects of changes caused by actions such as changing land use (such as plowing of permanent pasture) or intensification of agriculture is produced by the introduction of large areas of irrigation and drainage (Nikolski 1977, Aidarov et al. 1990, Aidarov and Pestov, Mosiej 1998, Shabanov 2002):

$\bar{R}=\frac{R}{L \cdot P}$

where:

$R$ - radiative balance of the soil surface $\left(\mathrm{kJ} / \mathrm{cm}^{2} \cdot\right.$ year$)$;

$P$-precipitation (mm); 
$L$ - latent heat of vaporization $(\mathrm{kJ} /$ $/ \mathrm{cm}^{2} \cdot$ year) per $1 \mathrm{~mm}$ of water layer.

More specifically, it should be present $\bar{R}$ in the amount of water permeating the soil or as effective precipitation $\left(P_{e}\right)$. Then expression takes the form:

$\bar{R}=\frac{R}{L \cdot P_{e}}$

Another important element of the assessment of the conditions of formation of the soil under the influence of constant changes in humidity (drainage or irrigation) are the energy loss of soil formation processes $-Q$ (Volobujev 1974, Kowalkowski 1988):

$Q=R \cdot e^{-\alpha \cdot \bar{R}}$

where:

$\alpha$ - fixed amount for the climate and soil zone (humid zone with $\bar{R}=0.5, \alpha=2.2$; for the temperate zone at $\bar{R}=1, \alpha=1.0$; for semi drought zone $\bar{R} \geq 1.5, \alpha=1.5$ ).

There is a close relationship between values $\bar{R}$ and $Q$ and the properties of soils in different areas of waterlogging. For multi-zone areas of Europe and Asia determined rather accurately the relationship between the values presented in Figure 1. From the point of view of optimizing the conditions for the soil forming processes most advantageous situation occurs when the $\left(\frac{R}{L \cdot P} \cong 1\right)$ in the temperate zone soil moisture. In this process the exchange of mass and energy are balanced, and the created soil are classified as different types of chernozem at the same time a relatively large stock of free energy is accumulated in decay, with a relatively high content of

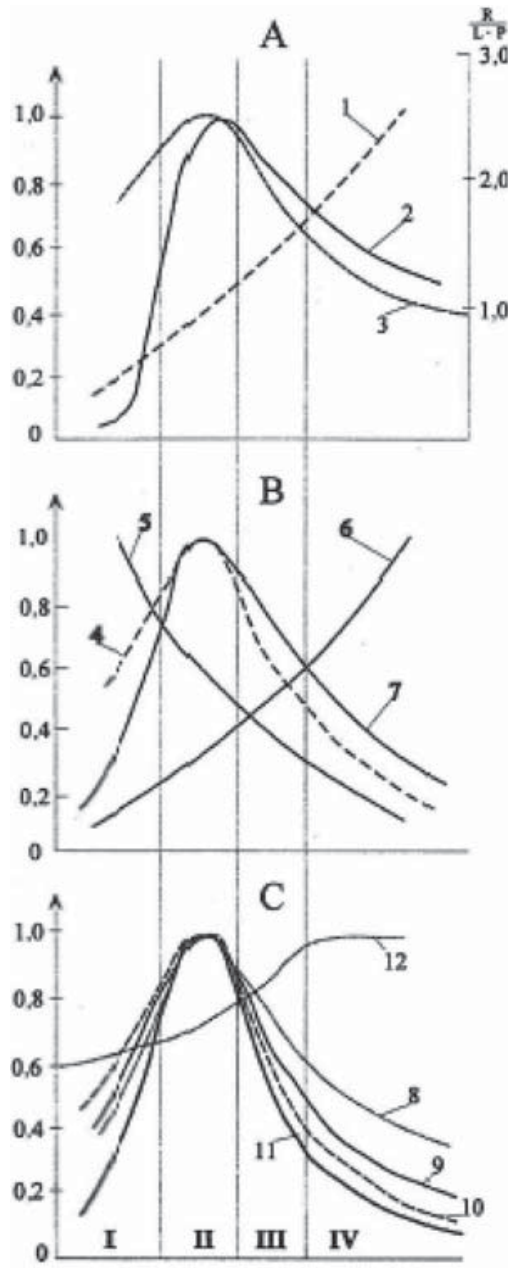

FIGURE 1. The relationship between factors of soil formation (A) and physico-moisture properties (B) and physicochemical (C) of soil: I - humid zone, II - steppe zone, III - dry steppe zone, IV - desert zone; 1 - relations $\bar{R}=\frac{R}{L \cdot P}, 2$ - the ratio of the annual quantities of organic matter accumulation on the surface and the topsoil to the size of the biomass produced, 3 - the energy of soil formation, $4-$ particle content $<0.001 \mathrm{~mm}$, 5 - soil moisture, 6 - soil sorption, 7 - water-resistant aggregates content, 8 - availability of nutrients for plants, 9 - the ratio: content of humic acids to content fulvic acids, 10 - complex sorption capacity of soils, 11 - organic matter content, $12-\mathrm{pH}$ value 
clay fraction and as a result have a high sorption capacity cation exchange, and the aggregates are relatively highly water resistant. In the desert area and in conditions of high temperatures and shortage of moisture $\frac{R}{L \cdot P} \geq 2$ biological soil productivity is relatively low, the organic substance is a very rapid mineralization, so that the humus content is low and the soil are characterized by relatively low sorption capacity cations.

Much worse soil properties humid zone and sub humid areas of the tropics, regardless of their sufficiently high biological productivity, are determined largely washed out not only minerals but also organic compounds $\left(\frac{R}{L \cdot P}<0.8\right)$. However, when $\frac{R}{L \cdot P}>1$ processes occur accumulation of chemicals in soils, soils and groundwater.

\section{THE COMPLEXITY OF THE ISSUES OF LAND IMPROVEMENT AND DRAINAGE}

Comprehensive approach the tasks related to the activities land improvement infrastructure (drainage and irrigation), taking into account environmental requirements is associated with the creation of system models describing the interaction of individual components of the circuit (biological and geological). This approach is not new, but previous actions both science land improvement (drainage and irrigation) and practices were focused mostly on one-sided meeting the needs of crops. They were omitted in these analyses both the conditions of soil formation and protection of the soil environment. Necessary becomes more comprehensive quantification of circulating water, minerals and organic and quantitative evaluation of the interaction processes occurring in the atmosphere, soils, biomass, groundwater and deeper aquifer. Currently, the lack of basic data prevents a full list of system models describing these phenomena. In practical terms, the justification drainage treatments is limited primarily to analyse the movement of moisture processes and substances, unrated their impact on the circulation of biological and geological and soil-forming processes (Golovanov 1975).

This system can be described by equations balance sheet, expressing the law of conservation of mass and energy (Shabanov 1973, 1980).

More specifically, the models mentioned system should consist of three main blocks characterized by:

- layer of the atmosphere at the ground surface;

- soil and plant;

- groundwater.

These blocks are characterized by:

- heat balance;

- water balance;

- balance of chemical components;

- balance of soil organic matter

The heat balance of the soil layer (at a certain time - year, vegetation period, month, decade):

$R=L \times E+B+S\left(\mathrm{~kJ} / \mathrm{cm}^{2}\right)$

where:

$R \quad$ - radiative balance of the soil surface $\left(\mathrm{kJ} / \mathrm{cm}^{2} \cdot\right.$ year $)$;

$L \times E$ - evaporative heat loss; 
$B \quad$ - heat exchange between the soil surface and the atmosphere (positive facing up);

$S \quad$ - heat exchange between the soil surface and bedrock located downstream (positive points down).

Water balance of the soil layer (within a specified period of time) in terms of appropriate conditions - natural conditions and with land improvement conditions:

- for the soil surface:

$\delta \bar{W}_{1}=P+D-E_{p}-W_{s}+(\bar{D}-\bar{O})(\mathrm{mm})$

- for root layer of soil (or for the unsaturated zone):

$\delta \bar{W}_{2}=W_{s}-E+q(\mathrm{~mm})$

- for groundwater:

$\delta \bar{W}_{3}=F-q+(\underline{D}+\underline{O})-Q+p(\mathrm{~mm})$

where:

$P$ - precipitation;

$E_{p}$ - evaporation from soil surface;

$E$ - evapotranspiration (evaporation + + transpiration + interception);

$W_{s}$ - infiltration (the amount of percolate water);

$D$ - periodical/seasonal irrigation rate;

$\bar{D}$ - surface inflow;

$\bar{O}$ - surface runoff;

$\underline{D}, \underline{O}$ - natural inflow and outflow of groundwater;

$\delta \bar{W}_{1}, \delta \bar{W}_{2}, \delta \bar{W}_{3}$ - change of surface water resources, in the root layer of the and ground water;

$F$ - losses on filtration from the irrigation network;

$\bar{D}, \bar{O}$ - natural inflow and outflow of surface waters;

$Q$ - drainage outflow; $q$ - volume of water exchange between soil moisture and groundwater (positive direction - up);

$p$-exchange of moisture between groundwater and deeper groundwater overhang (positive direction - up).

Balance of chemical components (both harmful salts and plant nutrients) to the soil surface):

$\delta G= \pm G_{o}+G_{W s}+G_{N}+G_{M} \pm G_{g}-$ $-G_{p}-G_{e}(\mathrm{t} / \mathrm{ha})$

where:

$\delta G$ - changes in the amount of chemicals in the soil in the period (multiplicity, decade, year, growing season, the irrigation period);

$G_{o}$ - chemical exchange between the soil solution and solid phase of soil;

$G_{W s}$-inflow to the soil from infiltrated surface water;

$G_{N}$ - inflow chemicals with mineral fertilizers;

$G_{M}$ - formation of the substance as a result of microbial fixation and soil microbial activity;

$G_{q}$ - inflow of substances from groundwater or outflow into groundwater;

$G_{p}-$ quantity of the substance taken up by the crop plants;

$G_{e}-$ loss of minerals from the soil due to wind and water erosion.

Balance of soil organic matter (for a specific period of time):

$\delta H=H_{p}+H_{N}+H_{M}+H_{g}+H_{e}(\mathrm{t} / \mathrm{ha})$

where:

$\delta H$ - change the resources of organic matter for the balance period; 
$H_{p}$ - inflow of organic matter (from seeds, crop residues of plants);

$H_{N}$ - bringing of organic matter in the form of organic fertilizers;

$H_{M}$ - mineralization of soil organic matter;

$H_{g}$ - leaching into groundwater;

$H_{e}-$ loss from the soil due to wind and water erosion.

In the above equations, the theory genesis and drainage of soils as closely related to each natural phenomenon linked into one system. The system of equations that altering one of balance sheets and the more one component of any balance is not real, since the formation of the soil and drainage is the result of a complex of all the factors.

Water conditions (humidity) are the most controllable indicator of soil fertility and largely determine the productivity of agricultural land. Their impact on air conditions, thermal, chemical and biological soil. The nature of this impact is presented in the balance equations and schematically shown in Figure 2.

The basic indicators of soil water relations are the soil moisture content $W$ and the depth of the groundwater $\Delta(\Delta$ size is very important especially with hydrogenic water regime), which determine the direction and intensity of moisture exchange.

If we use complex drainage solutions, such as:

- suitable agrotechnics on agricultural use;

- technical land improvement treatments (irrigation and drainage);

- agromelioration treatments (retention of snow, deep plowing of heavy soils, etc.);
- fitomelioration (including planting of trees and shrubs in the landscape); profiling the surface to increase or reduce the runoff.

Surface water balance, the amount of water percolates and energy of soil formation are changing as a result of the changed relationship evaporation and radiation balance. Carry out simulations presented in Figure 3.

The results of the calculations illustrated in the figures indicate that under moderate climate to be accelerated runoff in the range $0.2-0.3$ relative to the amount of rainfall. Steppe zone, on the contrary, it is necessary to exclude run-

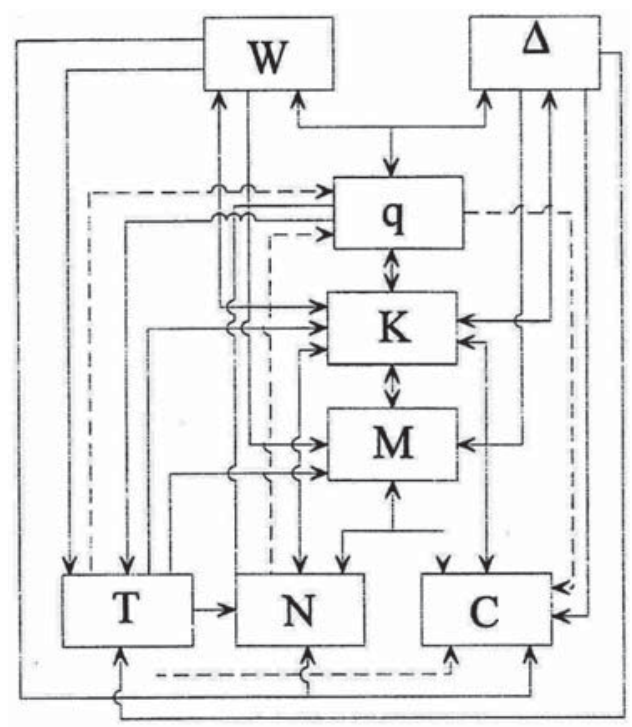

FIGURE 2. Diagram of the effect of regulating water relations on the thermal conditions $(\mathrm{T})$, chemical $(\mathrm{N})$, microbiological $(\mathrm{M})$, air condition (C) of soil: $M$ - microbial activity, $K$ - activity of the root system of plants, $W$ - soil moisture, $\Delta$ - depth groundwater, $q$ - the amount of moisture exchange; solid lines showing the close relationship, with dashed lines - weak relationship and the arrow indicated the direction of the impact (Aidarov et al. 1990) 


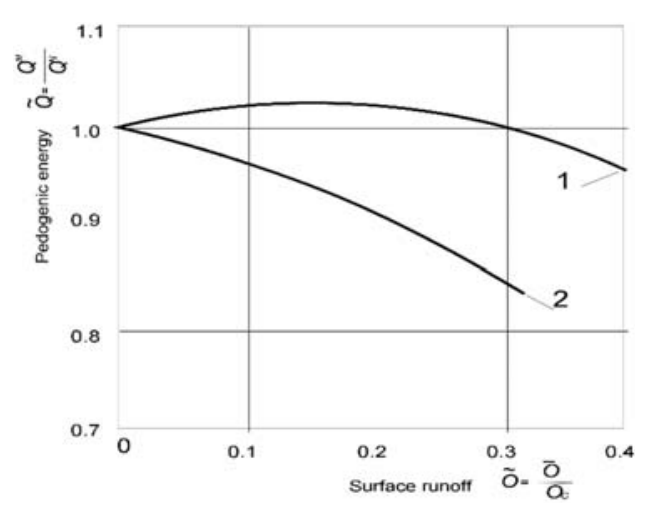

FIGURE 3. The impact of the relative runoff $\tilde{O}=\frac{\bar{O}}{P}$ on the relative energy loss of soil formation processes. $\tilde{Q}=\frac{Q^{M}}{Q^{N}}$ for humid conditions

(1) and for equilibrium water balance conditions (stepp zone) (2); symbol "M" means the area with melioration treatment (like drained), "N" - without any melioration treatment (conditions similar to the natural)

off through the use of appropriate agricultural treatments.

For practical control of natural processes necessary to their modelling. Models of soil processes should be based on the study of phenomena to move water, salt and heat, as well as nutritional compounds, creation and distribution of organic matter in soils, it is the study of the biological cycle of water, organic compounds and minerals.

Currently, most fully developed models the movement of moisture and chemical substances (salts). Much less developed models circulation of heat and practically insufficiently developed models the movement of nutrients and the creation and distribution of organic matter. This situation stems from practical reasons soils regulation of water: irrigation in arid and drainage in a zone of excessive moisture. So the task of land reclamation comes down to develop projects to compensate for the shortage of moisture and elimination of the excessive salinity and soil moisture.

Taking into account the issue would be concluded accepted evidence yet practical solutions to regulatory action. The moderate climate conditions, it is primarily the prevention of degradation of agriculture land, improving soil aeration for the active activities of root system of plants, the development of oxidative processes in soils and the weakening of the regime wash. The organic soils at certain times of the year should inhibit the development of oxidative processes to counteract too intense mineralization and smothering mass of peat. One of the tasks of regulating water relations in these areas should be by anti-pollution chemicals receivers leaving from drainage waters. For this purpose, it is essential to minimize dehydration regime wash areas and operate a system of closed water circulation. The problem that has not yet been adequately addressed in the assessment of the conditions for regulation of water is the fertility of the soil, as the value of habitats in the agricultural landscape.

\section{MATERIAL AND METHODS}

Soil water balance, is determined as part of the natural hydrologic cycle. As soil water declines, crops and other vegetation can become stressed. Changes in the amount of soil water in the root zone $(1 \mathrm{~m})$ for a selected time period $(t)$ is given as:

$\partial S / \partial t=P-E T-R_{O}-D_{r}\left(\mathrm{~m}^{3} / \mathrm{m}^{3}\right)$

where:

$\partial S / \partial t$ - change in soil water; 
$P \quad$ - precipitation;

$E T$ - evapotranspiration;

$R_{O} \quad$ - runoff;

$D_{r} \quad$ - drainage in evaluated time period $(t)$ in Equation (10).

The soil water content (S) is the equivalent depth of water:

$S=\Sigma \theta \Delta d\left(\mathrm{~m}^{3}\right)$

where:

$\theta$ - average volumetric water content of the soil over a layer of soil;

$\Delta d$ - thickness of the soil layer in Equation (11).

Soil water measurements reflect how effective a rainfall event was at replenishing a soil profile.

Available soil water fraction we can obtain using simple Equation (12):

$$
F S_{A W}=\left(\theta-\theta_{W P}\right) /\left(\theta_{F C}-\theta_{W P}\right)(-)
$$

where:

$\theta$ - measured volumetric soil water content;

$\theta_{F C}-$ volumetric soil water content at field capacity;
$\theta_{W P}$ - volumetric soil water content at the wilting point;

A centre of Excellence for Integrated Watershed Management in the Changing Environmental Conditions supported by EU funds is managed by a Faculty of Horticulture and Landscape Engineering. Specific goals of the centre are oriented on the creation of conditions for a research of a runoff creation and soil water dynamic in the main river basins of Slovakia.

A part of the centre is a network of meteorological and hydrological stations with online transfer of measurements (Kaletová 2015). The analysis of soil water storage during the drought season in 2015 was done according to information from those stations. There were chosen two stations - Dolné Naštice and Žirany (Fig. 4) for detailed description of soil water storage change in this paper.

We analysed an hour average data of soil moisture in depths: $10,20,30,40,50$, $75,100 \mathrm{~cm}$. Those data sets were the use for a calculation of soil water storage in the particular layer. Data for the missing layers were calculated as an average of

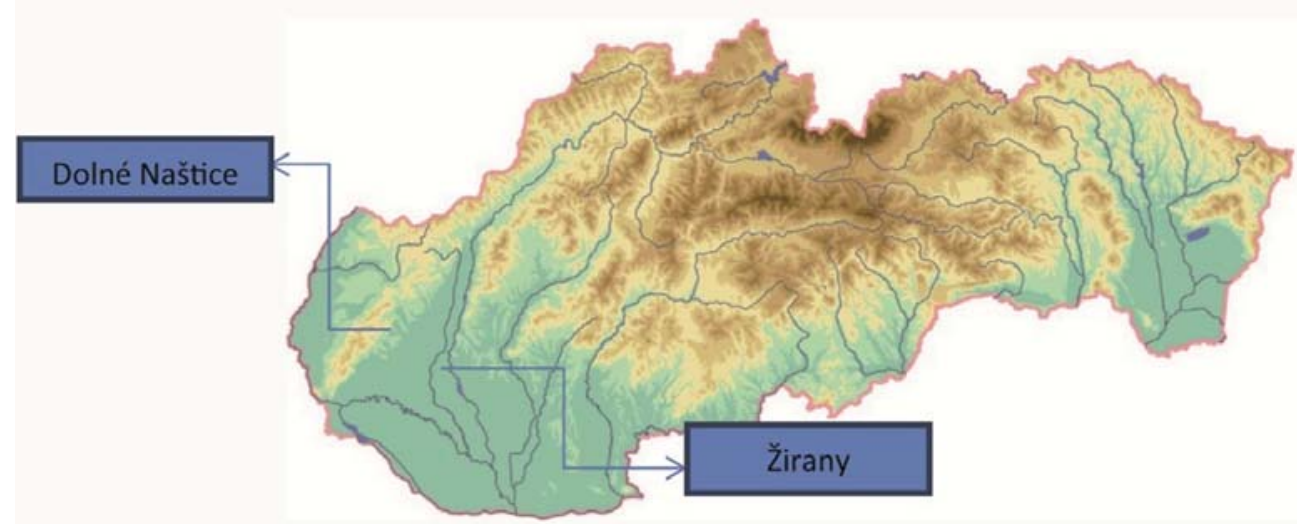

FIGURE 4. Places of soil water content measurement 
TABLE 1 . Field capacity $\left(\theta_{F C}\right)$ and wilting point $\left(\theta_{W P}\right)$ of particular depth of soil

\begin{tabular}{|c|c|c|c|c|}
\hline \multirow{2}{*}{$\begin{array}{c}\text { Depth } \\
(\mathrm{m})\end{array}$} & \multicolumn{2}{|c|}{ Dolné Naštice } & \multicolumn{2}{c|}{ Žirany } \\
\cline { 2 - 5 } & $\theta_{F C}$ & $\theta_{W P}$ & $\theta_{F C}$ & $\theta_{W P}$ \\
\cline { 2 - 5 } & \multicolumn{3}{|c|}{$\mathrm{m}^{3} / \mathrm{m}^{3}$} \\
\hline 0.10 & 0.335 & 0.209 & 0.372 & 0.230 \\
\hline 0.20 & 0.332 & 0.212 & 0.356 & 0.224 \\
\hline 0.30 & 0.278 & 0.170 & 0.342 & 0.221 \\
\hline 0.40 & 0.324 & 0.201 & 0.333 & 0.208 \\
\hline 0.50 & 0.300 & 0.187 & 0.333 & 0.200 \\
\hline 0.75 & 0.275 & 0.165 & 0.365 & 0.226 \\
\hline 1.00 & 0.358 & 0.220 & 0.313 & 0.307 \\
\hline
\end{tabular}

TABLE 2. Selected soil parameters of top layer $(15-20 \mathrm{~cm})$ and sub layer $(30-40 \mathrm{~cm})$ of soil profile

\begin{tabular}{|l|c|c|}
\hline Parameter & Top layer & Sub layer \\
\hline \multicolumn{3}{|c|}{ Dolné Naštice (Ostratice) } \\
\hline Soil texture classes & heavy soil & heavy soil \\
\hline Porosity $\left(\mathrm{m}^{3} / \mathrm{m}^{3}\right)$ & 0.44 & 0.4 \\
\hline Bulk density $\left(\mathrm{kg} / \mathrm{m}^{3}\right)$ & 1479 & 1500 \\
\hline$K_{S}(\mathrm{~m} / \mathrm{min})$ & $0.02883(1.73 \mathrm{~mm} / \mathrm{h})$ & $0.01475(1.27 \mathrm{~mm} / \mathrm{h})$ \\
\hline \multicolumn{3}{|c|}{ Žirany $($ Kolíňany) } \\
\hline Soil texture class & heavy soil & heavy soil \\
\hline Porosity $\left(\mathrm{m}^{3} / \mathrm{m}^{3}\right)$ & 0.44 & 0.405 \\
\hline Bulk density $\left(\mathrm{kg} / \mathrm{m}^{3}\right)$ & 1463 & 1492 \\
\hline$K_{S}(\mathrm{~mm} / \mathrm{min})$ & $0.02688(1.61 \mathrm{~mm} / \mathrm{h})$ & $0.03575(2.14 \mathrm{~mm} / \mathrm{h})$ \\
\hline
\end{tabular}

data from upper and lower layer as is layer with the missing data. The soil water storage in the whole soil profile up to $1 \mathrm{~m}$ was calculated as a sum of soil water storage of the particular soil layers (Tables 1,2).

Selected soil parameters are available at the Hydrophysics Webserver. The information was used for the nearest station to the place of measurement $\left(K_{S}\right)$ was estimated over field measurements.

\section{RESULTS}

According to information from Slovak Hydrological Institute in Bratislava, the total precipitation in western Slovakia were only $28 \%$ of normal in June and $38 \%$ in July, respectively. June and July of 2015 were extremely dry. Such situation were observed in other European countries (Laaha et al. 2016). A total monthly precipitation was up to $30 \mathrm{~mm}$ in June and $15 \mathrm{~mm}$ in July, respectively in the areas of interest (Fig. 5).

We observed 7 dry periods in 2013 and 2 periods in 2014 in Dolné Naštice. All of them were longer than 14 days; the longest one was 59 days in the summer 2013. There were 6 dry periods in 2013, and 4 periods in 2014 in Žirany. In this case, the longest one was 39 days.

Longer periods without precipitation were aborted with short, not heavy rains 

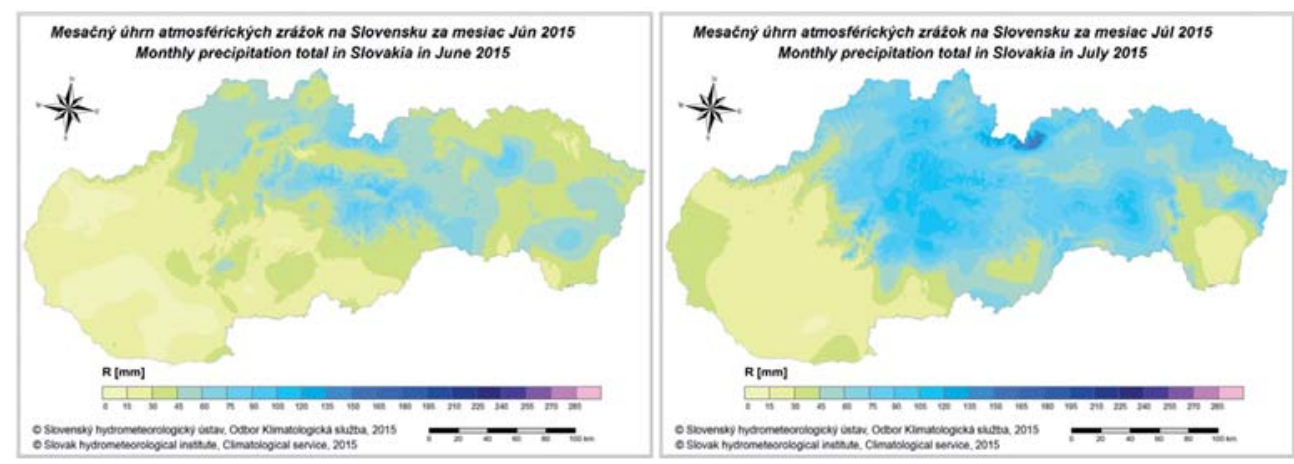

FIGURE 5. Monthly precipitation total in Slovakia in June (left) and July (right) in 2015 (retrieved from: http://www.shmu.sk/sk/?page=1610\&id=)

also in 2015. The period of 30 days with the descent of soil moisture in the top layer of soil $(10 \mathrm{~cm})$ were chosen for the analysis. There is visible a different trend of soil moisture in the particular layers in both stations.

The most critical soil water storage is in the depth $30-50 \mathrm{~cm}$, what is the main depth of water uptake by plant roots. The soil moisture in the depth $10 \mathrm{~cm}$ de- creased rapidly during the first 5 days, later, the trend was more balanced in the station Žirany. The soil moisture had the descent trend in all depths, except the depth $20 \mathrm{~cm}$ (Fig. 6). The lowest values of soil moisture were in the depth of $30 \mathrm{~cm}$ till the middle of analysed period, than it was in the depth of $75 \mathrm{~cm}$. The trend was similar in that time of period. The smallest values were in the depth of

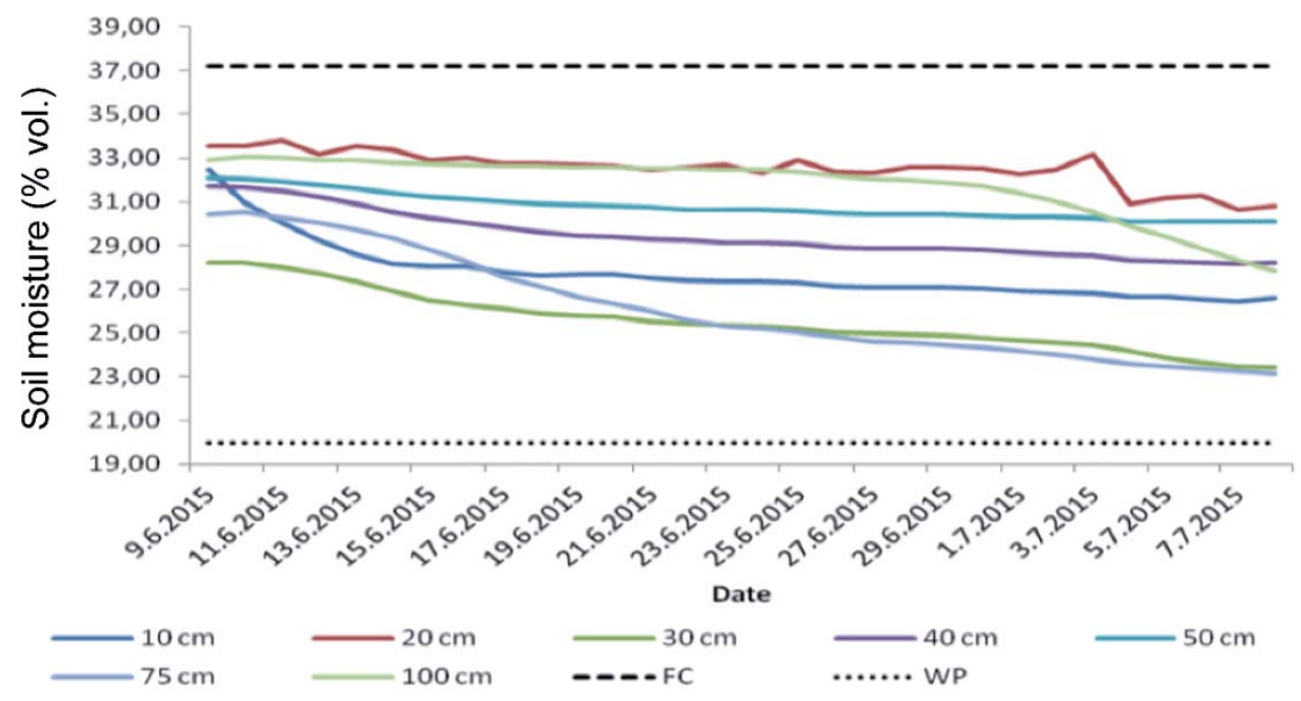

FIGURE 6. Soil moisture trend during the 30 days - station Žirany $(F C$ - field water capacity, WP - wilting point) 


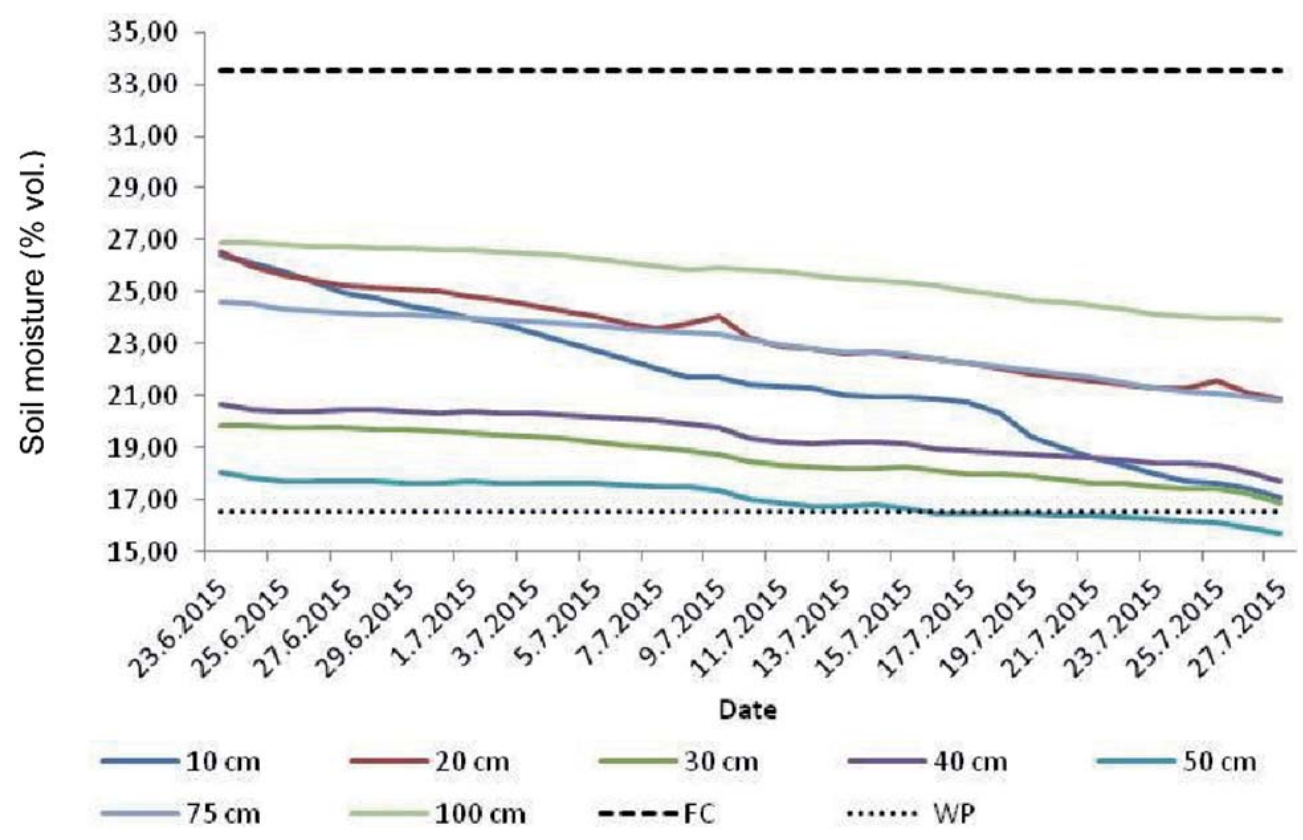

FIGURE 7. Soil moisture trend during the 35 days - station Dolné Naštice ( $F C$ - field water capacity, $W P$ - wilting point)

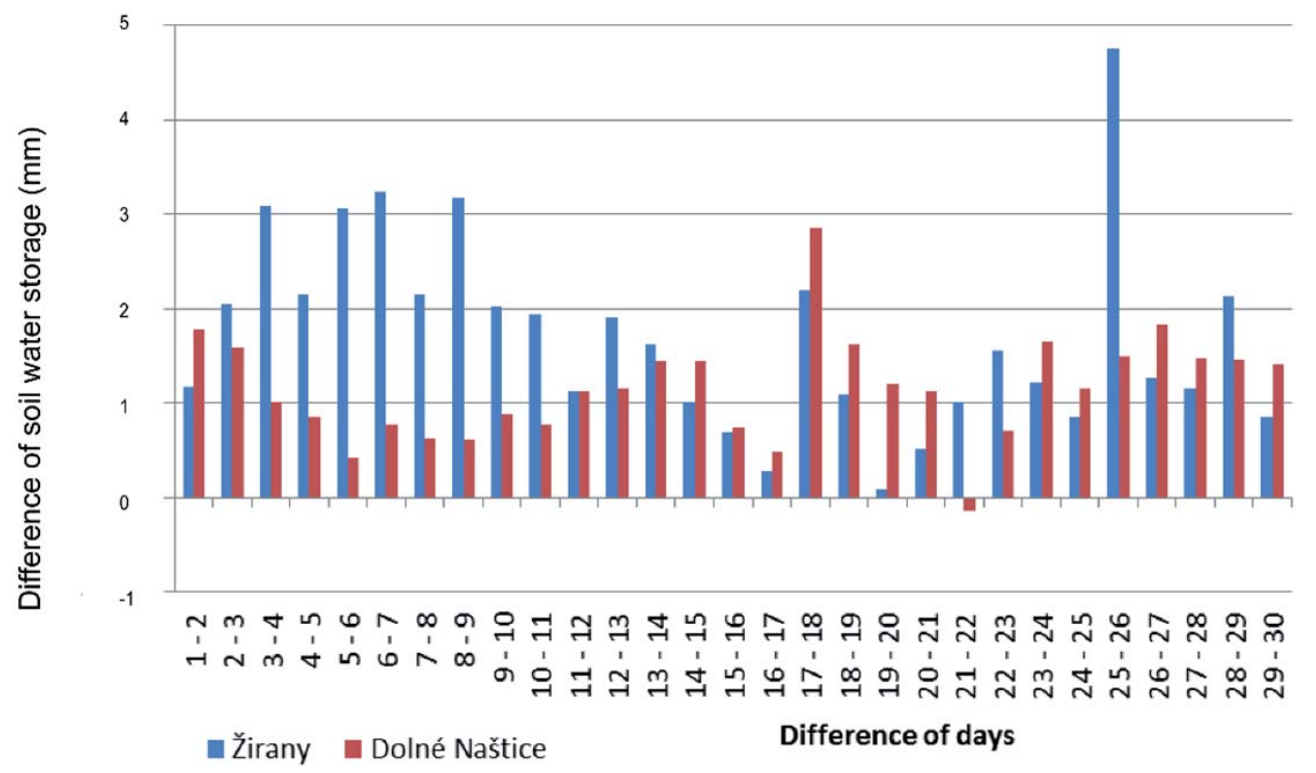

FIGURE 8. Daily difference of soil water storage in Žirany and Dolné Naštice 
20 and $100 \mathrm{~cm}$. At the end of the analysed period, the soil moisture in the depth of $100 \mathrm{~cm}$ was descent.

The trend of soil moisture in the station Dolné Neštice was similar as in station Žirany. It had also descent, but no so rapidly (Fig. 7). The highest descent was at the top layer, $10 \mathrm{~cm}(6 \%$ of volume). The lowest values of soil moisture were in the depth of $50 \mathrm{~cm}$ during the whole analysed period, and the highest one in the depth of $100 \mathrm{~cm}$. Kaletová and Tárnik (2015) obtained the similar result, the highest descent of soil moisture were in top layers up to $20 \mathrm{~cm}$.

There is no significant trend in the daily descent of soil water storage up to $100 \mathrm{~cm}$ (Fig. 8). The amount of soil water storage differ according to different conditions - meteorological, grown crops, soil type and soil structure, etc. The differences in station Dolné Naštice were smaller as in station Žirany. The curve of differences has a shape of sinus curve in Dolné Naštice. The trend in Žirany is totally different, and it is not possible to compare with some typical shape of curve. The daily variability of the differences is too high.

\section{SUMMARY}

1. Taking into account the issue would be concluded accepted evidence yet practical solutions to regulatory action. The moderate climate conditions, it is primarily the prevention of degradation of agriculture land, improving soil aeration for the active activities of root system of plants, the development of oxidative processes in soils and the weakening of the regime wash. The organic soils at certain times of the year should inhibit the development of oxidative processes to counteract too intense mineralization and smothering mass of peat. One of the tasks of regulating water relations in these areas should be by anti-pollution chemicals receivers leaving from drainage waters. For this purpose, it is essential to minimize dehydration regime wash areas and operate a system of closed water circulation. The problem that has not yet been adequately addressed in the assessment of the conditions for regulation of water is the fertility of the soil, as the value of habitats in the agricultural landscape.

2. Given that this issue would be included in the accepted evidence, there are still practical solutions to regulatory action. Moderate climatic conditions are primarily prevention of degradation of agricultural land, improvement of soil aeration for active functions of the root system of plants, development of oxidative processes in the soil and weakening of the washing regime. Organic soils in certain seasons should inhibit the development of oxidation processes to counteract too intensive mineralization and peat mass reduction. One of the tasks of regulating water relations in these areas should be receivers of measures to counteract pollution originating from drainage waters. For this purpose, it is necessary to minimize the washing areas of the dehydration system and to start the closed water cycle. The problem that has not been adequately taken into account when assessing the condi- 
tions of water regulation is soil fertility as the value of habitats in the agricultural landscape. One of the tasks of regulating water relations in these areas should be activities limiting the processes of mineralization of organic matter in order to limit the outflow of nutrients through drainage systems.

3. The paper presents the analysis of drought problem in the environment. A parameterization of soil water storage in the zone of aeration is based on the soil water trend in the specified soil layer with the specified high and hydrolimits wilting point, permanent wilting point and field capacity. Nowadays, there is totally different situation with the soil water content monitoring. It is possible to measure soil water content continuously in the high precision with the online transfer. The output from the system is not useful for the practice. The output from the database managed by SHMI is 1 week later as measured, what may cause the catastrophic impact on the field crops. Therefore, it is necessary to solve the methodology of drought evaluation in the landscape.

\section{Acknowledgements}

The paper was supported by the grant - APVV-16-0278 "Use of hydromelioration structures for mitigation of the negative extreme hydrological phenomena effects and their impacts on the quality of water bodies in agricultural landscapes".

Experimental data to this paper are as result of project realization: Centre of Excellence for Integrated Watershed Management in the Changing Environmental Conditions, ITMS 26220120062; supported by the research and develop- ment operational program financed from European Regional Development Fund.

\section{REFERENCES}

AIDAROV I.P., PESTOV L.F. 2002: Drainage of Irrigated Land. In: Agricultural land improvement: amelioration and reclamation. Vol. I. EOLSS Publishers, Oxford.

AIDAROV I.P., GOLOVANOV A.I., NIKOLSKY Y.N. 1990: Optimization of irrigated and drained agricultural lands ameliorative regimes. Moscow. Agropromizdat, 58 [Criteria, models and technique of water, salt and nutricut regimes optimisation on irrigated and drained soils]. [In Russian].

BENEDICTOV O.J. 2004: The Black Death 1346-1353: The Complete History. Boydell Press, Woodbridge.

GOLOVANOV A.I., SUKHAREV Y.I., SHABANOV V.V. 2006: Integrated regional planning - a further stage of land reclamation. Irrigat. Water Manag. 2: 25-31.

KALETOVÁ T., TÁRNÍK A. 2015: Pokles vlhkosti pôdy počas bezzrážkového obdobia. [Decrease of soil water moisture during the time without precipitation]. In: Krajinné inžinierstvo - Problémy, trendy a perspektívy 2015. Nitra: SPU: 16-25 [in Slovak].

KEENAN R.J. 2015: Climate change impacts and adaptation in forest management: a review. Ann. Forest Sci. 72 (2): 145-167. DOI 10.1007/s13595-014-0446-5

KOWALKOWSKI A. 1988: Age and the genesis of soils. In: Transformation of the geographical environment in Poland. Polish Academy of Sciences, Warszawa.

KUNDZEWICZ Z.W., KOZYRA J. 2017: Climate change impact on Polish agriculture. In: Z.W. Kundzewicz, O. Hov, T. Okruszko (Eds.) Climate change and its impact on selected sectors in Poland: 158-171. 
LAAHA G., GAUSTER T., TALLAKSEN L.M., VIDAL J-P., STAHL K., PRUDHOMME CH., HEUDORFER B., VLNAS R., IONITA M., Van LANEN H.A. J., ADLER M.-J., CAILLOUET L., DELUS C., FENDEKOVA M., GAILLIEZ S., HANNAFORD J., KINGSTON D., Van LOON A.F., MEDIERO L., OSUCH M., ROMANOWICZ R., SAUQUET E., STAGGE J.H., WONG W.K. 2016: The European 2015 drought from a hydrological perspective. Hydrol. Earth Syst. Sci. Discuss. DOI 10.5194/hess2016-366

LINDNER M. 2000: Developing adaptive forest management strategies to cope with climate change. Tree Physiol. 20 (5-6): 299-307.

MOSIEJ J. 1998: Optimization criteria of humidity conditions in the reclaimed areas. In: Water-balance criteria shaping of habitats in the rural landscape. Wydawnictwo SGGW, Warszawa: 25-41 [in Polish].

NAUMANN G., SPINONI J., VOGT J.V., BARBOSA P. 2015: Assessment of drought damages and their uncertainties in Europe. Environ. Res. Letters 10, \# 124013.

NIKOLSKI Y.N. 1977: The dependence of irrigation requirements on water -table depth in drained lands. Agric. Water Manage. 1: 191-196.

SHABANOV V.V. 2002: The necessity for development of land reclamation. In: Food and agricultural engineering resources. Vol. III, 14. UNESCO, EOLSS Publishers, Oxford: 29.

SOHN J.A., SAHA S., BAUHUS J. 2016: Potential of forest thinning to mitigate drought stress: A meta-analysis. Forest Ecol. Manag. 380: 261 November. DOI 10.1016/j.foreco.2016.07.046

ŠÚTOR J., REHÁK Š. 2009: Problematika vody v zóne aerácie pôdy s ohl'adom na integrovaný manažment povodí, súčasnú legislatívu a smernicu EÚ [Water issues in the soil aeration zone with regard to integrated river basin management, current legislation and EU directive]. Acta Hydrolog. Slovaca 1: 94-108.

VOLOBUJEV V.P. 1974: Introduction to energetic processes in soil sciences. Nauka, Moscow.

Streszczenie: Środowiskowe skutki wzrostutemperatury i dlugich okresów bez opadów atmosferycznych na procesy glebowe - studium przypadku dla potudniowej Stowacji. W związku z pojawiającymi się coraz częściej anomaliami klimatycznymi związanymi m.in. z długimi okresami bezopadowymi i wysokimi temperaturami lub z nadmiernymi i intensywnymi opadami atmosferycznymi należałoby przeanalizować konsekwencje środowiskowe, a przede wszystkim wpływ tych anomalii na przebieg procesów środowiskowych oraz procesy związane $\mathrm{z}$ kształtowaniem środowiska glebowego. Praca dotyczy dosyć istotnego zagadnienia, jakim jest ocena wpływu zmieniających się wskaźników klimatycznych, głównie wskaźników hydrotermicznych (temperatura powietrza i wskaźnik opadów) na kierunek przebiegu procesów glebowych. Oczywiście praca nie obejmuje całości problemu jedynie jest pewnym przyczynkiem do kierunku rozwoju nauk melioracyjnych. Praca składa się z dwóch części. Pierwsza dotyczy teoretycznych podstaw kształtowania środowiska przyrodniczego, a przede wszystkim przebiegu procesów zachodzących w pedosferze pod wpływem zmian czynników klimatycznych, takich jak temperatura powietrza i wielkość opadów atmosferycznych. Druga część jest klasycznym studium przypadku dla dwóch obiektów zlokalizowanych w południowej Słowacji, w której przedstawiono wyniki obserwacji zasobów wody glebowej w dosyć długim okresie bezopadowym.

Stowa kluczowe: bilans cieplny, bilans wodny, czynniki hydrotermiczne, susza glebowa

MS received 10.12.2016

MS accepted 10.09.2018 


\author{
Authors' address: \\ Luboš Jurík \\ Department of Water Resources \\ and Environmental Engineering \\ Faculty of Horticulture and Landscape \\ Engineering \\ Slovak University of Agriculture in Nitra \\ Hospodárska 7, 94976 Nitra, Slovakia \\ e-mail: lubos.jurik.nr@gmail.com
}

